\title{
A Comparative Study of Government and Private School Teachers to Explore the Causes of Absenteeism at Secondary Level in District Bahawalnagar, Punjab, Pakistan
}

\author{
Misbah Akhtar \\ The Islamia University of Bahawalpur, Pakistan \\ misbah.akhtar@iub.edu.pk
}

\begin{abstract}
The major objective of the study was to compare the different reasons of absenteeism between private and public school teachers at secondary level in district Bahawalnagar, Punjab, Pakistan. Sample of 160 participants was selected.80 participants were from government schools and 80 were from private schools. A questionnaire was used as a research tool. For the analysis of data percentages were find out. It was find out that government teachers avail more leaves than private teacher. Job security, lenient attitude of principle, different functions in the family, transport problems and illness are the main reasons of the teachers' absenteeism from school. Teacher of private schools avail less leaves because they feel insecure and are unsatisfied with their jobs and working environment.
\end{abstract}

Key words: Teacher Absenteeism, Government schools, Private schools, Secondary level, Pakistan

\section{Introduction}

Education in Pakistan is the basic responsibility of Ministry of Education and provincial governments. Federal governments mostly help for curriculum development, authorization and finance the research (Bundy, 2002).To provide the quality education different government and public schools are working at different levels. Teachers plays key role in teaching learning g process. Pakistan's system of education facing many problems. One of the most serious problems i-e Teacher absenteeism is an issue that is affecting developing as well as developed countries. It affects the economies, it school and students. Researchers are strongly in this favor that teacher absentees badly affect the school effectiveness and results a hindrance in the achievement of student's achievement and it also results in student's absenteeism (Hackett, 2009).First of all let's see what is absenteeism? Voluntary non attendance at work, without valid reason. Absenteeism means either habitual evasion of work, or willful absence as in a strike action. It does not include involuntary or occasional absence due to valid causes, or reasons beyond one's control, such as accidents or sickness. http://www.businessdictionary.com/definition/absenteeism.html.

It is clearly evident from researches that teacher's absenteeism effects the learning of the students and performance of the exams (Obeng-Denteh, Asiamah Yeboah, Sam \& Esi Monkah, 2012).Parents of the students give importance to the different factors while selecting schools for their children i-e teachers effort, cleanliness and orderliness of schools and perception of teacher absence(Sathar \& Lloyd, 2000).The studies of(Woods \& Montagno, 1997) showed that large no of absences of teacher effect the student achievement negatively. Pakistan is a developing country and Pakistan ranks at 113th position among 120 countries of the world and literacy rate is only 57\%(Bajwa, 2011).Low literacy is due to many reasons in which poverty, lack of awareness, gender discrimination and government's mismanagement play fundamental role. Different issues regarding schools also a cause of low literacy e.g. drop out of student, school's infrastructure, strict attitude of teachers and teachers absenteeism especially in rural areas. District Bahawalnagar is a backward district in Pakistan where literacy rate is very low and teachers remain absent from schools frequently.Very less no of researches has been done especially on educational issues. That's why researcher selected this area and this topic for the research. So this research will address very important issue i-e teacher's absenteeism.

\section{Literature Review}

The literature available on teacher absenteeism shows that absent rate of teacher in developing countries is high. A report on primary education on India shows that one -third principles were not absent when their 
schools were visited by Public Report on Basic Education (PROBE) Team(PROBE, 1980). In India another study was conducted on Uttar Pradesh and Madya Pradesh showed that $17 \%$ teachers were absent from schools.20\% of present teachers were not present in classes(Rao \& Narasimha, 1999; Unit, 2001). Another study conducted on the North West Frontier Province in Pakistan presented the facts that absent rate of school teachers was there 18\%(Ali \& Reed, 1994).A study held by world bank in Bangladesh in the mid 1990s showed that $50 \%$ teachers were absent frequently (Bank, 2001). It was discovered that absent ratio of teachers in India was found $25 \%$. During unannounced visits to a nationally representative sample of government primary schools. It was observed that teacher's absence was more correlated with daily incentives to attend work. Absent rate was less where inspection was done regularly, have better infrastructure and were closer to the road(Kremer, Chaudhury, Rogers, Muralidharan, \& Hammer, 2005). It was find out that in Pakistan absent rate among female teachers is greater than the male teachers. About 25\% of enrolled girls and $17 \%$ of enrolled boys in government schools did not have teachers present in the school. It was find that those teachers who are appointed in their local community have less absent rate than those who come from outside the city or village (Ghuman \& Lloyd, 2010). One of the reasons of teacher absents was found that teacher's absent rate is positively linked with the how generously leaves are available to the employees by the departmental head(Ehrenberg, Ehrenberg, Rees \& Ehrenberg, 1991).

Previous studies also shows that teaching years in schools, teacher's level of education, teachers training are not linked with lower absence(Chaudhury, Hammer, Kremer, Muralidharan \& Rogers, 2004).On the other side teacher's high salary and seniority were consistently related to high rate of absence, perhaps they were protected from any monitoring system(Kremer et al., 2005). Lower answerability of teachers is also a reason teacher's absenteeism in schools because assignment of teachers is done on political bases(Hasnain, 2008). In another study different reasons of absenteeism have been described. The reasons were below-average teachers' salaries, above-average teacher salaries, teacher unions, lack of social accountability and the social protection of a profession that is short in supply(Christine Harris, 2009). Several scholars have emphasized the lack of motivation from teachers side, congested class rooms, meager infrastructural facilities, vacant vacancies, load of non academic tasks, lack of adequate training to deal with multi-lingual and multi-ability classes, declining social status of the teaching profession and increasing social class differences between teachers and the clientele of government schools (Mooij \& Narayan, 2010).

Objectives of the study: Following were the objectives of the study to

- Find out different reasons of teacher absenteeism at secondary school in District Bahawalnagar, Pakistan.

- Sort out personal, professional and economic factors involved in the teacher's absenteeism at secondary level in District Bahawalnagar, Pakistan.

- Compare the reasons of teacher's absenteeism between government and private school in District Bahawalnagar, Punjab, Pakistan.

\section{Methodology}

Population: All government and private school teachers of District Bahawalnagar comprised the population of the study.

Sample: From government and private schools sample of 160 teachers of secondary level was selected. There are five tehsiles of District Bahawalnagar i-e Bahawalnagar, Fortabbas, Minchanabad, Chishtian and Haroonabad. From each tehsil two schools were selected randomly. One school was from government sector and other was from private sector. From each school 16 students of $10^{\text {th }}$ class were selected randomly. In this way 80 students were selected from private and 80 from government schools.

Research Instruments: A questionnaire for secondary schools teachers was developed as a research tool.

Data collection and Analysis: Researcher personally visited the schools and collected the data .Then data was analyzed by using percentage. 


\section{Results}

Table 1: Monthly income

\begin{tabular}{lllll}
\hline & Private & \% age & Government & \% age \\
\hline 1-5 Thousand & 7 & 8.75 & 0 & 0 \\
6-10 Thousand & 18 & 22.5 & 0 & 0 \\
$\begin{array}{l}\text { 10-20 Thousand } \\
\begin{array}{l}\text { More than 20 } 20 \\
\text { Thousand }\end{array}\end{array}$ & 25 & 37.5 & 17 & 21.25 \\
\hline
\end{tabular}

Table 1 shows that $37.5 \%$ teachers of private school receive pay within the range of $10-20$ thousand, $31.25 \%$ receive more than 20 thousand, $22.5 \%$ within the range of $6-10$ thousands and $8.75 \%$ receive pay from one to five thousand. On the other side $78.75 \%$ teachers of government schools receive more than twenty thousand and $21.25 \%$ within the range of $10-20$ thousands.

Table 2: How many days do you usually take leave per month?

\begin{tabular}{lllll}
\hline & Private & \% age & Government & \% age \\
\hline $\begin{array}{l}\text { 0 leave } \\
\begin{array}{l}1-5 \text { days } \\
\text { leave }\end{array}\end{array}$ & 52 & 65 & 25 & 31.25 \\
$\begin{array}{l}5-10 \text { days } \\
\text { leave }\end{array}$ & 2 & 27.5 & 55 & 68.75 \\
$\begin{array}{l}\text { above 10 } \\
\text { days leave }\end{array}$ & 3 & 2.5 & 0 & 0 \\
\hline
\end{tabular}

Table 2 shows that $65 \%$ teachers of private schools avail no leave, $27.5 \%$ avail from one to five days, $3.75 \%$ avail more than ten days per month. On the other side $68.75 \%$ teachers of government school avail 1-5 leaves per month and $31.25 \%$ teachers don't avail any leave.

Table 3: Causes of Absenteeism due to Personal Problems

\begin{tabular}{|c|c|c|c|c|c|c|}
\hline \multirow{3}{*}{ Statement } & \multicolumn{2}{|c|}{ Government } & \multirow[b]{2}{*}{$\begin{array}{l}\text { To } \\
\text { some } \\
\text { extent }\end{array}$} & \multicolumn{2}{|l|}{ Private } & \multirow[b]{2}{*}{$\begin{array}{l}\text { To some } \\
\text { extent }\end{array}$} \\
\hline & Yes & No & & Yes & No & \\
\hline & $\%$ age & $\%$ age & $\%$ age & $\%$ age & $\%$ age & $\%$ age \\
\hline You like your job. & 95 & 3 & 3 & 68 & 24 & 9 \\
\hline $\begin{array}{l}\text { When you feel ill you don't go } \\
\text { to school. }\end{array}$ & 41 & 53 & 8 & 33 & 36 & 28 \\
\hline $\begin{array}{l}\text { In case of function in your } \\
\text { family e.g. marriage, you don't } \\
\text { go to school. }\end{array}$ & 56 & 30 & 14 & 50 & 30 & 18 \\
\hline $\begin{array}{l}\text { You don't go to school in case of } \\
\text { any emergency in your home. }\end{array}$ & 55 & 14 & 30 & 68 & 10 & 21 \\
\hline $\begin{array}{l}\text { You have transport problems. } \\
\text { Due to transport problems you }\end{array}$ & 54 & 41 & 3 & 31 & 63 & 4 \\
\hline $\begin{array}{l}\text { sometimes avoid to go to } \\
\text { school. }\end{array}$ & 31 & 68 & 3 & 15 & 69 & 15 \\
\hline
\end{tabular}


Table 3 shows that majority teachers of government schools like their jobs as compared to private school teachers, government school teachers avail more leaves as compare to private school teachers when they feel ill, more teachers of government school avail leaves on functions, mostly government teachers have transport problem than teachers of private schools and they avail more leaves than private school teachers.

Table 4: Causes of Absenteeism Due to School Related Problems

\begin{tabular}{|c|c|c|c|c|c|c|}
\hline \multirow{3}{*}{ Statement } & \multicolumn{2}{|c|}{ Government } & \multirow{3}{*}{ 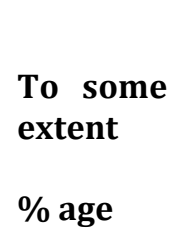 } & \multicolumn{2}{|c|}{ Private } & \multirow{3}{*}{$\begin{array}{l}\text { To } \\
\text { some } \\
\text { extent } \\
\% \text { age }\end{array}$} \\
\hline & Yes & No & & Yes & No & \\
\hline & $\%$ age & $\%$ age & & $\begin{array}{l}\% \\
\text { age }\end{array}$ & $\%$ age & \\
\hline $\begin{array}{l}\text { Your colleagues } \\
\text { cooperative attitude with you. }\end{array}$ & 93 & 0 & 8 & 89 & 8 & 3 \\
\hline $\begin{array}{l}\text { You feel secure about your job } \\
\text { security. }\end{array}$ & 81 & 11 & 8 & 45 & 38 & 14 \\
\hline $\begin{array}{l}\text { Your principle rewards you } \\
\text { when you achieve a target. }\end{array}$ & 88 & 10 & 3 & 64 & 26 & 10 \\
\hline Your principle gives & & & & & & \\
\hline $\begin{array}{l}\text { importance to your } \\
\text { suggestions. }\end{array}$ & 88 & 3 & 10 & 66 & 18 & 15 \\
\hline $\begin{array}{l}\text { You are satisfied with working } \\
\text { hours in your school. }\end{array}$ & 90 & 9 & 3 & 78 & 19 & 3 \\
\hline You are satisfied with your job. & 90 & 0 & 8 & 69 & 16 & 14 \\
\hline $\begin{array}{l}\text { You are satisfied with working } \\
\text { environment in your school. }\end{array}$ & 83 & 8 & 10 & 75 & 16 & 9 \\
\hline $\begin{array}{l}\text { You take leave with prior } \\
\text { permission. }\end{array}$ & 98 & 0 & 3 & 80 & 9 & 11 \\
\hline
\end{tabular}

Table 4 show that mostly government teachers feel more secure than private teachers. Head teachers of government schools reward more when they achieve goal as compare to heads of private schools. Principles of government schools involve its staff more than the head teachers of private school. Government teachers are more satisfied with their jobs and working environment than the private schools teachers.

\section{Conclusion}

It is concluded that teachers of government schools have better salary than the teachers of private schools. All teachers of government schools have pay more than twenty thousands and no teachers receive less than ten thousands while $22.5 \%$ teachers of private schools withdraw salary within the range of 6-10 thousands and $8.5 \%$ also receive within the range of $1-5$ thousands. It was also concluded that mostly private teachers don't avail any leave in a month. Mostly government teachers avail 1-5 leaves per month. It is because of strict environment in private schools that teachers avail less leaves than the teachers of government schools. As compare to private teachers government teachers like their jobs. They feel better in the working environment of the schools and feel more satisfied than the teachers of private school. Teachers of private school are less satisfied with their working environment, job and feel insecure about job. That's why they avail less no of leaves as compare to government school teachers.

\section{References}

Ali, M. \& Reed, T. (1994). A school and parental survey of book provision issues in NWFP. International Book Development, Ltd.

Bajwa, A. (2011). Out of School Children in Sindh: Looking at Access \& Equity Annual Status of Education Report: ASER Pakistan facilitated by SAFED.

Bundy, D. (2002). Education and HIV/AIDS: A window of hope. Washington DC: World Bank Group. 
Chaudhury, N., Hammer, J., Kremer, M., Muralidharan, K. \& Rogers, F. H. (2004). Roll call: Teacher absence in Bangladesh. Harvard University and World Bank

Christine Harris, V. K. (2009). Teacher Absenteeism and Teacher Accountability (USAID Paper): USAID Ed Strategy Development.

Ehrenberg, R. G., Ehrenberg, R. A., Rees, D. I. \& Ehrenberg, E. L. (1991). School district leave policies, teacher absenteeism, and student achievement. Journal of Human Resources, 26, 72-105.

Ghuman, S. \& Lloyd, C. (2010). Teacher absence as a factor in gender inequalities in access to primary schooling in rural Pakistan. Comparative Education Review, 54(4), 539-554.

Hackett, R. S. (2009). Teacher Absenteeism. School of Education, UWI, St. Augustine, http://hdl.handle.net/2139/8983

Hasnain, Z. (2008). The Politics of Service Delivery in Pakistan: Political Parties and the Incentives for Patronage, 1988-1999. The Pakistan Development Review, 2, 129-151.

Kremer, M., Chaudhury, N., Rogers, F. H., Muralidharan, K. \& Hammer, J. (2005). Teacher absence in India: A snapshot. Journal of the European Economic Association, 3(2-3), 658-667.

Mooij, J. \& Narayan, K. (2010). Solutions to Teacher Absenteeism in Rural Government Primary Schools in India: A Comparison of Management Approaches. The Open Education Journal, 3, 63-71.

Obeng-Denteh, W., Asiamah Yeboah, E., Sam, C. \& Esi Monkah, J. (2012). The impact of student and teacher absenteeism on student performance at the junior high school: the case of the kumasi-metro school district. Continental Journal of Education Research, 4(1).

PROBE, T. (1980). The (1999): Public Report on Basic Education in India: New Delhi: Oxford University Press.

Rao, G., \& Narasimha, L. (1999). Teachers absenteeism in primary school: a field study in select districts of Madhya Pradesh and Uttar Pradesh. New Delhi: District Primary Education Programme.

Sathar, Z. A. \& Lloyd, C. B. (2000). Investments in Children's Education and Family-Building Behavior in Pakistan: Findings from Rural NWFP and Punjab. Economic Development and Cultural Change, 53(3). doi: $10.1086 / 427042$

Unit, E. S. (2001). Expanding and Improving Upper Primary Education in India.

Woods, R. C. \& Montagno, R. V. (1997). Determining the negative effect of teacher attendance on student achievement. Education-Indianapolis, 118, 307-316.

URL: http://www.businessdictionary.com/definition/absenteeism.html. 